\title{
Management of Pulmonary Hydatid Cyst With Pleural Complications: A Case Series
}

\author{
Authors: \\ *Anshuman Darbari,, Raja Lahiri, ${ }^{1}$ Mayank Mishra, ${ }^{2}$ Ajay Kumar, ${ }^{3}$ \\ Sandeep Gautam, ${ }^{1}$ Navin Kumar ${ }^{4}$ \\ 1. Cardiothoracic and Vascular Surgery Department, All India Institute of Medical \\ Science Rishikesh, Uttarakhand, India \\ 2. Pulmonary Medicine Department, All India Institute of Medical Science Rishikesh, \\ Uttarakhand, India \\ 3. Cardiothoracic Anaesthesia Department, All India Institute of Medical Science \\ Rishikesh, Uttarakhand, India \\ 4. General Surgery Department, All India Institute of Medical Science Rishikesh, \\ Uttarakhand, India \\ *Correspondence to darbarianshu@gmail.com \\ Disclosure: $\quad$ The authors have declared no conflicts of interest. \\ Received: \\ 16.07.20 \\ Accepted: $\quad 21.10 .20$ \\ Keywords: $\quad$ Cystic echinococcosis, hydatid cyst, lung, pleura. \\ Citation: $\quad$ EMJ. 2021;DOI/10.33590/emj/20-00179.
}

\begin{abstract}
Introduction: The aim of this observational, retrospective study was to review and describe clinical presentations and management of patients with pulmonary hydatid cysts (PHC) and pleural complications.

Methods: Complete case records from the previous 2 years were reviewed, including operative steps and follow-up of patients with PHC and pleural complications. Only four cases that presented with pleural complications were found out of 14 cases of surgically managed PHC.
\end{abstract}

Results: The most common symptoms in all patients were chest pain and fever. In all cases, the lower lobes of the lung were involved. Lung resection surgery was not required in any case. There was no postoperative respiratory failure or immediate or late mortality in any of these patients. The mean follow-up was 10 months for all these cases, with no pulmonary recurrence or complications.

Conclusion: Pulmonary parenchymal sparing surgical interventions are deemed to be the safest curative treatment for complicated PHC. Spontaneous pyopneumothorax can also be caused by complicated PHC.

\section{INTRODUCTION}

Hydatid cyst formation is a silent zoonotic disease caused by infection with Echinococcus granulosus metacestodes. Humans act as accidental intermediate hosts and the most

common cyst sites are the liver and lung, but they may also be located in other organs, such as the brain, heart, and spleen. Because of slow cyst growth, pulmonary hydatidosis is often asymptomatic. Pulmonary hydatid cyst (PHC) often becomes symptomatic after cyst rupture in the pleural cavity or bronchus. In these cases, 
PHC may be misdiagnosed with other diseases and therefore patients may receive inappropriate treatment.' Surgical methods for dealing with $\mathrm{PHC}$ include enucleation of intact cysts and cystotomy, with or without capitonnage, or lung resection for complicated or intact cysts. The ideal surgical technique and outcomes for $\mathrm{PHC}$ with pleural complication are unknown, and still the technique continues to be performed at the choice of the surgeon.

\section{METHODS}

On reviewing case records of patients with surgically managed $\mathrm{PHC}$ at the authors' institute within the last 2 years (2018-2019), only four out of 14 cases of PHC presented with pleural complications.

Of these four patients, there were two males and two females, with a mean age of 38 years. Three of these patients already had spontaneous pyopneumothorax. Two patients presented with a chest tube in situ. In one patient, a chest tube was used to stabilise them before operating. Another patient was found to have localised pleural thickening with a locally contained, leaking, ruptured cyst during operation. This patient had been given preoperative antihelminthic drugs after PHC diagnosis. Plain chest radiography, haematological tests, and contrast enhanced CT of the thorax with abdomen and ultrasonography was performed in all cases.

\section{RESULTS}

The most common symptoms in all four patients were chest pain and fever, followed by dyspnoea in three patients. No patients had skin eruptions, rashes, anaphylactic episodes, or haemoptysis. In three patients the cysts were unilateral. The hydatid cyst presented in the right lung in one patient and in the left lung in the other three patients. In all cases, the lower lobes of the lung were involved. The standard posterolateral thoracotomy incision was used in all cases for surgical exploration. The surgical techniques required were residual cystectomy with repair of the bronchial openings plus capitonnage and decortication. A double-lumen endobronchial tube and coverage of the uninfected area with scolicidal agent during the operative procedure and postoperative drug therapy were used in all cases to prevent recurrence. Lung resection surgery was not required in any case. Only one patient had long-standing postoperative air leak, though this proceeded to heal spontaneously. There was no postoperative respiratory failure and no patients needed long-term mechanical ventilation. There was no mortality in this case series. The mean follow-up was 10 months for all cases, and there was no pulmonary recurrence or complications. Complete case details are summarised in Table 1.

Table 1: Summary of pulmonary hydatid cases presented with pleural complications.

\begin{tabular}{|l|l|l|l|l|}
\hline & Case One & Case Two & Case Three & Case Four \\
\hline Age (years) & 35 & 58 & 32 & 28 \\
\hline Sex & Male & Male & Female & Female \\
\hline Side of pulmonary cyst & Left & Left & Left & Left and right \\
\hline Site of pulmonary lobe & Lower & Lower & Lower & Lower \\
\hline $\begin{array}{l}\text { Associated hepatic } \\
\text { involvement }\end{array}$ & No & Yes & No & Yes \\
\hline History of animal contact & Sheep and pet dogs & Sheep and pet dogs & Pet dog & Pet dogs \\
\hline Clinical manifestations & Chest pain & Chest pain & Chest pain & Chest pain \\
& Fever & Fever & Fever & Fever \\
& Dyspnoea & Dyspnoea & Dry cough \\
Dry cough & Fatigue & & \\
\end{tabular}


Table 1 continued.

\begin{tabular}{|c|c|c|c|c|}
\hline & Case One & Case Two & Case Three & Case Four \\
\hline $\begin{array}{l}\text { Preoperative } \\
\text { complications }\end{array}$ & $\begin{array}{l}\text { Left } \\
\text { pyopneumothorax }\end{array}$ & $\begin{array}{l}\text { Left } \\
\text { pyopneumothorax }\end{array}$ & None & $\begin{array}{l}\text { Left } \\
\text { pyopneumothorax }\end{array}$ \\
\hline Chest X-ray & $\begin{array}{l}\text { Suggestive of left } \\
\text { pyopneumothorax } \\
\text { and intercostal drain } \\
\text { in situ; no defined } \\
\text { pulmonary cystic } \\
\text { lesion (Figure 1). }\end{array}$ & $\begin{array}{l}\text { Suggestive of left- } \\
\text { sided basal haziness; } \\
\text { empyema; blurred } \\
\text { shadow of pulmonary } \\
\text { cystic lesion present. }\end{array}$ & $\begin{array}{l}\text { Giant pulmonary cyst } \\
(12 \mathrm{~cm}) \text {; no pleural } \\
\text { finding. }\end{array}$ & $\begin{array}{l}\text { Bilateral pulmonary } \\
\text { cystic lesion } \\
\text { present with left } \\
\text { pneumothorax; } \\
\text { empyema. }\end{array}$ \\
\hline CT scan & \begin{tabular}{|l|} 
Large left \\
hydropneumothorax \\
with serpiginous \\
coiled up membranes \\
in dependent parts, \\
likely ruptured \\
hydatid cyst with \\
bronchopleural \\
communication.
\end{tabular} & $\begin{array}{l}\text { Small left } \\
\text { hydropneumothorax } \\
\text { with floating particles } \\
\text { and membranes in } \\
\text { dependent parts, } \\
\text { a likely ruptured } \\
\text { hydatid cyst } \\
\text { with suspected } \\
\text { bronchopleural } \\
\text { communication. } \\
\text { Few tree-in-bud } \\
\text { nodules in left lower } \\
\text { lobe suggestive of } \\
\text { infective aetiology } \\
\text { (Figure 2). }\end{array}$ & $\begin{array}{l}\text { Superior segment of } \\
\text { left lower lobe lung } \\
\text { showing well-defined } \\
\text { peripheral enhancing } \\
\text { lesion (size: } 12 \times 7 \times 6.5 \\
\text { mm). Hydatid cyst } \\
\text { likely in transitional } \\
\text { stage. }\end{array}$ & $\begin{array}{l}\text { Complex cyst (size: } \\
64 \times 47 \times 48 \mathrm{~mm} \text { ) } \\
\text { in the left lower } \\
\text { lobe of lung with } \\
\text { air fluid levels and } \\
\text { floating membranes, } \\
\text { with moderate } \\
\text { pleural effusion, } \\
\text { consolidation in the } \\
\text { left lower lobe. There } \\
\text { was also a large } \\
\text { simple cyst seen in } \\
\text { the right lung (size: } \\
4.6 \times 4.0 \times 5.9 \text { mm) and } \\
\text { in the right lobe of } \\
\text { the liver. }\end{array}$ \\
\hline $\begin{array}{l}\text { Antihelminthic drug } \\
\text { therapy }\end{array}$ & Postoperatively & Postoperatively & $\begin{array}{l}\text { Preoperatively; } \\
\text { started upon } \\
\text { diagnosis and } \\
\text { continued } \\
\text { postoperatively }\end{array}$ & Postoperatively \\
\hline $\begin{array}{l}\text { Tube thoracostomy } \\
\text { (preoperative) }\end{array}$ & $\begin{array}{l}\text { Yes (already from } \\
\text { outside) }\end{array}$ & No & No & $\begin{array}{l}\text { Yes (before } \\
\text { operation) }\end{array}$ \\
\hline Surgery Incision & $\begin{array}{l}\text { Left posterolateral } \\
\text { thoracotomy }\end{array}$ & $\begin{array}{l}\text { Left posterolateral } \\
\text { thoracotomy }\end{array}$ & $\begin{array}{l}\text { Left posterolateral } \\
\text { thoracotomy }\end{array}$ & $\begin{array}{l}\text { Left posterolateral } \\
\text { thoracotomy }\end{array}$ \\
\hline Intraoperative finding & \begin{tabular}{|l|} 
Empyema with \\
hydatid cyst contents \\
lying freely in pleural \\
space. Cavity with \\
significant air leak.
\end{tabular} & $\begin{array}{l}\text { Empyema with } \\
\text { ruptured hydatid } \\
\text { cyst. Some contents } \\
\text { lying freely in pleural } \\
\text { space. Cyst wall } \\
\text { attached to cavity } \\
\text { with minor air leak. }\end{array}$ & $\begin{array}{l}\text { Localised hydatid } \\
\text { cyst rupture attached } \\
\text { to pleura with small } \\
\text { extrapulmonary } \\
\text { empyema cavity } \\
\text { contained pus } \\
\text { and debris. Pleural } \\
\text { thickening. No air } \\
\text { leak. }\end{array}$ & $\begin{array}{l}\text { Empyema with } \\
\text { ruptured hydatid } \\
\text { cyst. Some contents } \\
\text { lying freely in pleural } \\
\text { space. Cyst wall } \\
\text { attached to cavity } \\
\text { with minor air leak. }\end{array}$ \\
\hline Procedure & $\begin{array}{l}\text { Cystectomy, } \\
\text { capitonnage, and } \\
\text { decortication. }\end{array}$ & $\begin{array}{l}\text { Cystectomy, } \\
\text { capitonnage, and } \\
\text { decortication. }\end{array}$ & $\begin{array}{l}\text { Cystotomy, } \\
\text { capitonnage, and } \\
\text { decortication. }\end{array}$ & $\begin{array}{l}\text { Cystectomy, } \\
\text { capitonnage, and } \\
\text { decortication. }\end{array}$ \\
\hline $\begin{array}{l}\text { Postoperative } \\
\text { complication }\end{array}$ & $\begin{array}{l}\text { Prolonged air } \\
\text { leakage, resolved in } 3 \\
\text { weeks }\end{array}$ & No & No & No \\
\hline $\begin{array}{l}\text { Postoperative hospital } \\
\text { stay }\end{array}$ & 14 days & 10 days & 10 days & 9 days \\
\hline Mortality & No & No & No & No \\
\hline
\end{tabular}




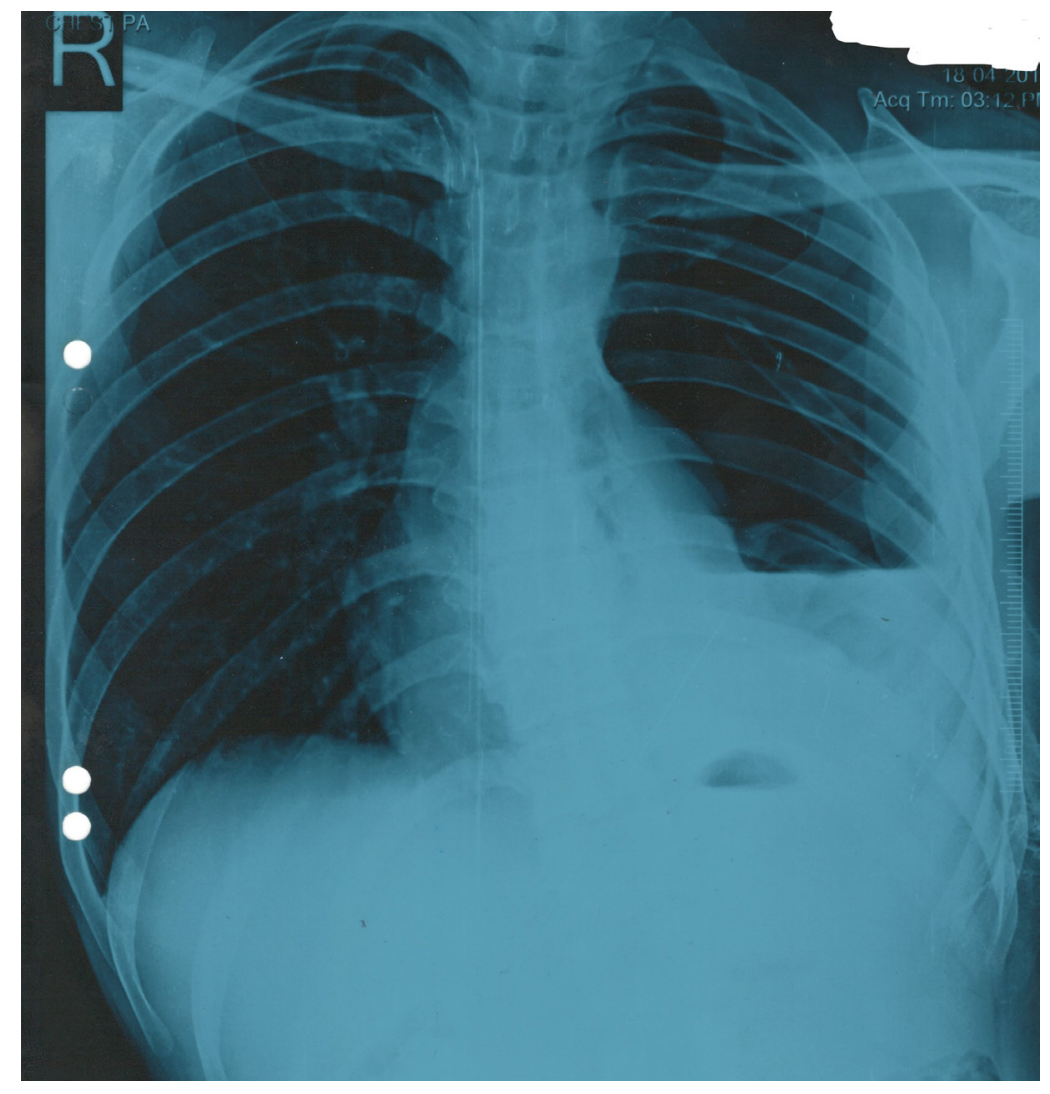

Figure 1: Chest X-ray showing massive left pneumothorax with collapsed left lung and intercostal drain in situ (Case One).

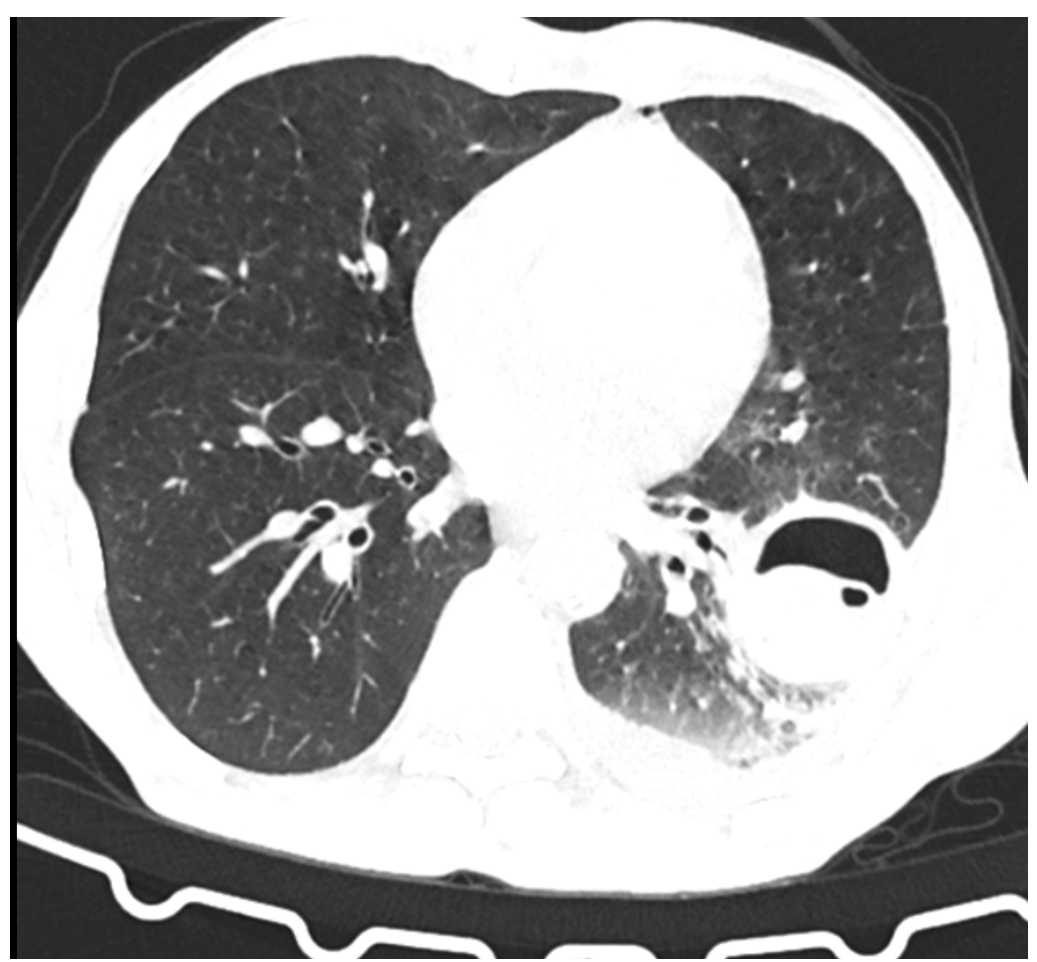

Figure 2: Chest CT scan of a patient with a cyst cavity in the posterobasal segment of the left lower lobe adhered to the lateral chest wall with loculation in the cyst and air-fluid level (perforated hydatid cyst) (Case Two). 


\section{DISCUSSION}

Hydatid disease is one of the most important

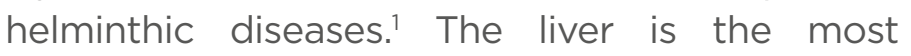
effected organ, followed by the lungs (almost $25 \%$ of cases) in patients with hydatidosis. The lung may be affected when the liver is bypassed via the lymphatic system.' One of the unusual complications of pulmonary hydatidosis is rupture, which can occur spontaneously when it reaches $7-10 \mathrm{~cm}$ in diameter, secondary to an infectious process, or after coughing, trauma to the chest, or needle aspiration., ${ }^{2,3}$ In the study by Aribas et al. ${ }^{4}$ of 145 patients with complicated hydatid cysts of the lung, $88 \%$ had ruptured cysts and $16 \%$ had both intact and ruptured cysts. In another study involving 537 patients with PHC, 87 (16\%) had ruptured cysts, with a higher incidence in cysts $>10 \mathrm{~cm}$ in diameter (27\% versus $15 \%){ }^{5}$ Another study by Sayir et al. ${ }^{6}$ revealed a similar percentage of rupture (18\%).

The clinical appearance is inconstant for these complicated perforated hydatid cysts and depend upon the characteristics of perforation. The cyst frequently ruptures into the bronchus but in some cases it ruptures into the pleura. Usually, rupture can be classified into three types: contained, communicating, and direct. In most cases, the solid residues in the collapsed parasitic membrane cavity are the source of the recurrent infection. Coughing sputum, chest pain, haemoptysis, dyspnoea, and fever are the most common symptoms of complicated $\mathrm{PHC}$. Rupture of a hydatid cyst into the pleural cavity can cause pneumothorax, pleural effusion, or empyema. Cyst rupture into the pleural cavity can also result in tension pneumothorax. ${ }^{8}$

Serologic tests are used in the diagnosis and follow-up of patients with hydatid cysts in endemic regions because of their low cost and convenient administration. Serologic tests that can be used in the diagnosis and follow-up of hydatid cysts include Echinococcus indirect hemagglutination, ELISA, IgG measuring, immunoelectrophoresis, and indirect fluorescent antibody testing. CT scans of the thorax have an important role in patients with complicated PHC. There are various signs that help to diagnose a ruptured hydatid cyst in a CT scan including air crescent or meniscus, Water Lily or Camelotte, Cumbo, and air bubble and signet ring signs. ${ }^{9}$
Surgical treatment remains the most valid method of treatment for a PHC, regardless of whether it is symptomatic. The aim of surgical intervention is removal of the germinative membrane without causing intraoperative contamination and preventing an intrapulmonary residual cystic space. Therefore, varying techniques, such as enucleation, pericystectomy, and simple cystotomy with or without capitonnage of the pericystic space, can be chosen in appropriate conditions during the operation. ${ }^{4}$ Surgical treatment should be performed by preserving the lung parenchyma where possible. Resection should not be avoided if complications develop (e.g., significant infection) or if there is bronchiectasis. ${ }^{6}$ Bacterial infection is one of the most serious complications of a perforated cyst, leading to empyema. Decortication is necessary in such cases because of pleural contamination and pleural thickening.

Pulmonary resection must be avoided as much as possible. However, segmental resection, wedge resection, and lobectomy are justified when lesser procedures are excluded because of the size and number of cysts and degree of infection. The principal indications for lobectomy are large cysts involving more than $50 \%$ of the lobe, cysts with severe pulmonary suppuration not responding to treatment, multiple unilobar cysts, and a sequelae of hydatid disease such as bronchiectasis, pulmonary fibrosis, or severe haemorrhage, as capitonnage or any other procedure leads to complications in such patients. ${ }^{10}$

In the literature, various surgical techniques and procedures have been described for management of PHC, but in complicated scenarios, especially in pleural rupture, these procedures can be very difficult to perform because of ill-defined planes and extensive adhesions as a result of intense pleural reaction. A more feasible surgery in this case would be cystectomy or, in the case of nonsalvageable lung tissue, limited anatomical resection. Turna et al. ${ }^{10}$ failed to show an advantage of added capitonnage procedures, but this study is demerited by its small sample size and nonstandardised criteria for defining significant postoperative air leak.

The choice between a cystectomy and a limited resection or segmentectomy usually depends on the individual surgeon's experience and 
judgement about the condition of the adjacent lung tissue. ${ }^{11}$ In this case series, three out of the four cases did not have a well-defined plane for a cystotomy. However, the lung tissue was amenable to repair and hence a cystectomy was performed, followed by capitonnage. Even similarly designed studies have shown contrasting results. ${ }^{12}$ A large retrospective study by Yaldiz et al. ${ }^{13}$ showed acceptably low complication rates with capitonnage. Capitonnage has been shown to have superior results in children compared to cystotomy alone. ${ }^{14}$

The authors routinely performed capitonnage in all cases at their institute. As it is essential to have a well-expanded lung at the end of the surgical procedure, decortication was required in almost all cases of ruptured hydatid cyst into the pleural cavity.

Research has shown that $73-75 \%$ of patients may respond to medical management; however, the reported cure rates are only 25$30 \%$. Anthelmintics weaken the cyst wall, thus increasing the likelihood of cyst rupture. ${ }^{10}$ Every patient who has hydatid cysts of the lung should be investigated for associated cysts in the liver. Many liver cysts can be approached from a thoracic route after incising the diaphragm..$^{15}$ When bilateral cysts are present, some surgeons prefer a one-stage operation via a median sternotomy and this method is applicable when bilateral lung and liver cysts are present. A two-stage thoracotomy is preferred by some surgeons, as sternotomy carries its associated risk of mediastinitis. The side with the larger, ruptured, and infected cyst is operated on first. The period between two thoracotomies varies from 3 weeks to 2 months. ${ }^{4,6}$

Medical therapy with benzimidazoles is clearly valuable in disseminated disease, including secondary lung or pleural hydatidosis, in poor surgical risk patients, and in cases of intraoperative spillage of hydatid fluid. Albendazole is given in two divided doses of $10-15 \mathrm{mg} / \mathrm{kg}$ body weight/ day, the usual adult daily dose being $800 \mathrm{mg}$. Therapy is most often indicated for a minimum of 3-6 months. ${ }^{16}$ Prevention of hydatid disease can often be achieved by avoiding close contact with dogs and sheep. Careful washing of vegetables and products can also reduce infection. Prohibition of domestic slaughtering of sheep and proper offal disposal prevents dogs from consuming infected viscera, thus disrupting the life cycle of the parasite and stoping transmission. Reducing numbers of stray dogs and surveillance techniques, including coproantigen tests, could also help to reduce infections in some endemic areas. ${ }^{16}$

\section{CONCLUSIONS}

In this case series, presence of pyopneumothorax was found in the majority of complicated cases but ultimately good outcomes were achieved with surgical intervention. Lung-sparing surgical interventions are the most feasible and safest curative treatment for complicated PHC with rupture in pleural space, offering negligible morbidity and mortality. Further it can be concluded that complicated hydatid cyst should also be considered in the differential diagnosis of spontaneous pyopneumothorax. Use of preoperative drug therapy in these cases is not established and theoretically medical therapy can cause cyst rupture and further complications.

\section{PATIENT CONSENT}

Patients and relatives were well informed and signed consent forms regarding publishing their data and photographs. Anonymity during reporting was also taken with due care.

\section{References}

1. Kaur M, Singh R. Ruptured pulmonary hydatid cyst: the camalote sign. Indian J Clin Prac. 2013;23(12):856-8.

2. Karimi M et al. Ruptured pulmonary hydatid cyst: a case report. J Parasit Dis. 2017;41(3):899-902.
3. Puri D et al. Ruptured hydatid cyst with an unusual presentation. Case Rep Surg. 2011;2011:730604.

4. Aribas OK et al. Pleural complications of hydatid disease. J Thorac Cardiovasc Surg. 2002;123(3):492-7.
5. Usluer $O$ et al. Surgical management of pulmonary hydatid cysts. Tex Heart Inst J. 2010;37(4):429-34.

6. Sayir F et al. Surgical treatment of pulmonary hydatid cysts, which perforated to the pleura. Eurasian J Med. 2012;44:79-83. 
7. Cobanoglu U et al. Therapeutic strategies for complications secondary to hydatid cyst rupture. Int J Clin Exp Med. 2011;4(3):220-6.

8. Kuzucu A et al. Complicated hydatid cysts of the lung: clinical and therapeutic issues. Ann Thorac Surg. 2004;77(4):1200-4.

9. Sarkar $\mathrm{M}$ et al. Cystic pulmonary hydatidosis. Lung India. 2016;33(2):179-91.

10. Turna A et al. Surgical treatment of pulmonary hydatid cysts: is capitonnage necessary? Ann Thorac Surg. 2002;74(1):191-5.

11. Nabi S, Waseem T. Pulmonary hydatid disease: what is the optimal surgical strategy? Int J Surg. 2010;8(8):612-6.

12. Bilgin $\mathrm{M}$ et al. Is capitonnage unnecessary in the surgery of intact pulmonary hydatic cyst? ANZ J Surg. 2004;74(1-2):40-2.

13. Yaldiz $\mathrm{S}$ et al. Capitonnage results in low postoperative morbidity in the surgical treatment of pulmonary echinococcosis. Ann of Thorac Surg.
2012;93(3):962-6.

14. Kosar A et al. Effect of capitonnage and cystotomy on outcome of childhood pulmonary hydatid cysts. J Thorac Cardiovasc Surg. 2006;132(3):560-4.

15. Yalcinkaya I et al. Surgical treatment of hydatid cyst of the lung: review of 30 cases. Eur Respir J. 1999;13(2):441-4.

16. Morar R, Feldman C. Pulmonary echinococcosis. Eur Respir J. 2003;21(6):1069-77. 